\title{
Corporate Governance and profitability: Evidence from Indian IT companies
}

\section{T. Prusty}

Associate Professor, Faculty of Commerce, Banaras Hindu University, India

Waleed M. Al-ahdal

Research scholar, Faculty of Commerce, Banaras Hindu University, India

\begin{abstract}
Corporate governance provides the guidelines to the companies how can be directed and controlled. The objective of this study is to examine the relationship between corporate governance mechanisms and profitability for the IT companies listed Indian stock Exchange. The focus was on some corporate governance mechanisms such as board size (BS), audit committee meeting (ACM), and audit committee independence (ACI). The dependent variables are return on assets (ROA), return on equity (ROE). While the control variable is firm size. The analysis results revealed a significant relationship between corporate governance variables board size, audit committee meeting, audit committee independence and firm size of the company and profitability measured by return on assets. However, the findings revealed that audit committee meeting and board size had insignificant relationship with profitability measuring by return on equity while audit committee independence and firm size significantly impacted. This study contributes to the literature by providing an analysis of the impact of corporate governance on profitability in Indian IT firms.
\end{abstract}

Key words: Corporate Governance, Financial Performance, IT Firms, India.

\section{JEL Classification G3, G34.}

\section{Introduction}

Corporate governance refers to the set of systems, principles and processes by which a company's governed. It is all about doing right actions for the betterment of the companies' performance by the right people on board as well as company. Increasing competition, pressure on billing rates of traditional services and increasing commoditization of lower-end services are among the key reasons forcing the Indian software industry to make a fast move up in the software value chain. The companies are now providing higher valueadded services like consulting, product development, R\&D as well as new digital technologies like social media, mobility, analytics, and cloud computing (SMAC). The new Indian government is emphasizing on better technology enabled delivery mechanisms for a multitude of government projects (Vishwakarma \& Kumar, 2015). Further, with the new digital India initiative being launched, the domestic market for software services looks forward to a bright future. India's IT industry can be divided into five main components, viz. Software Products, IT services, Engineering and R\&D services, ITES/BPO (IT-enabled services/Business Process Outsourcing) and Hardware. Export revenues, primarily on project based IT Services continue to drive growth with IT Services. This accounts for $54.2 \%$ of total revenues followed by BPO and Engineering services at $19.5 \%$, Software Products at $15.3 \%$ and hardware at $11 \%$. The Indian IT/ITES industry earned revenue of over US\$ 109 billion during the FY2014. Out of this, exports accounted for $69.7 \%$ of the industry's revenue. At the end of FY14, India's share in the global outsourcing market stood at 55\%.The USA accounts for about $53 \%$ of the export revenue followed by the UK and Continental Europe, with $15 \%$ and $10 \%$ respectively. Other regions such as Asia Pacific are catching up, with a contribution of $6.5 \%$. Indian IT companies had a good year in terms of financial performance, driven by factors like such as the improvement in the quality of service offerings, stable pricing environment and the depreciation of the Indian rupee. One of the main reason of increasing capitalization and profitability due to their manpower and management that understand the competitiveness' of dynamic environment and work for the companies effectively and efficiently. They are mainly directed by the board of directors who mainly gives the strategic direction to the companies. Strong governance has long been considered crucial for enhancing the long-term value of stakeholders in the business environment and also influential in the development and functioning of economy and exerts a strong influence on resource allocation which impacts on the performance of firms. Corporate Governance has attracted considerable attention, debate and research worldwide in recent decades(Mandal \& Al-ahdal, 2018). The absence of good corporate governance is a major cause of failure of many well performing companies. The economic wellbeing of a nation is the reflection of the performance of its companies. The OECD (2004) Principles of Corporate Governance acknowledge that an effective corporate governance system can lower the cost of capital and encourage firms to use resources more efficiently, thereby 
promoting growth. Good corporate governance is a desired feature of a liberalized market to ensure the flow of both foreign and domestic capital for accelerated economic development. This is because it increases investor confidence and goodwill, ensures transparency, fairness, responsibility and accountability.

Financial performance used to know firm's overall financial health over a given period of time and can also be used to compare similar firms across the same industry or to compare industries or sectors in aggregation. Dhaliwal et al., (2007)mentioned that quality of financial reporting and the effectiveness of the audit committee are correlated to each other. Their analysis give us the idea that the level of independent audit committee will enhance the quality of accounting. These is important because shareholders require good quality of financial statements to make correct judgments and decisions. So, Audit committee should prepare good quality of financial statements and to keep along with the changes in accounting standard. Financial performance analysis is the process of identifying the financial strengths and weaknesses of the firm. There must be good relationship between the items of balance sheet and profit and loss account. It also helps in short-term and long-term forecasting and growth of the organization. It can be derived with the help of financial performance analysis (Al-ahdal et al., 2018). The analysis of financial statement is a process of evaluating the relationship between the component parts of financial statement and it's done to get better understanding of the firm's position and performance respectively. This analysis should be undertaken by the management of a firm or by parties outside the namely, the owners, the creditors and the investors (Alahdal et al.,2016).

The significance of the corporate governance has arisen because of the increasing concern of the noncompliance of standards of financial reporting and accountability by board of directors and management of corporate inflicting heavy losses to the investors. Financial Performance in a broader sense refers to the degree of the financial objectives being or has been accomplished in the case of finance risk management (Tabash et al.,2017). So, it is measure the results of a firm's policies and operations in monetary terms. Most importantly good corporate governance will attract more investors to invest in a company because it helps to protect their investments. This study will provide an additional view to the current literature based on the impact of corporate governance on profitability of Indian IT firms.

The rest of this study is organized as follows; the next section provides a review of literature and hypotheses development; the second section discusses the research methodology. Finally, the third section presents the results and findings of the study.

\section{Literature Review and hypotheses development}

In India, Corporate governance concepts emerged after the second half of 1996 due to economic liberalization and deregulation of industries and businesses. As a regulator of securities market The Securities and Exchange Board of India had begun to seek equity capital in financial expansion. That helps to reform the corporate governance and based on it many initiatives have been launched in India. Corporate governance need arises due to separation of management from the ownership and its financial performance. A firm need to concentrate on their economic and social aspect. So, it must be fair with producers, shareholders, customers etc. The performance of the firm can be seen from its financial statements which are reported by the company. Basically the success of the firm is measured through its financial performance which is analyzed through different tools and techniques. These indicators brings out the internal performance of the company and shows the earning aspect of the company. Many studies have been done on various aspects of corporate governance and its impact on the financial performance for example, Ararat et al., (2017) studied the corporate governance practices of Turkish public firms from 2006 to 2012, relying on hand-collected data covering the vast majority of listed firms. They build a Turkey Corporate Governance Index, TCGI, composed of sub-indices for board structure, board procedure, disclosure, ownership, and shareholder rights. The study find that most firmspecific factors have little effect on firms' governance choices. Also, Mohamed et al.,(2016) focused on corporate governance practices among top 100 public listed companies in Bursa Malaysia from 2008 to 2012, and the relationship between corporate governance practices with firm performance. The result showed that board size has significantly weak negative relationship with ROA but it was found to be insignificant to ROE. The other finding indicated that there was no relationship between board independence and firm performance. In addition, Arora \& Sharma (2016) found that return on equity and profitability is not related to corporate governance indicators. They suggest that $\mathrm{CEO}$ duality is not related to any firm performance measures for the sample firms .Furthermore, Bhardwaj et al., (2014) have found that majority of companies studied are merely complying to mandatory requirements and disclose information required by the revised clause 49 while few 
companies such as Bajaj auto, Infosys, Dr. Reddy, etc. are disclosing information beyond the mandatory levels as required by clause 49.Moreover, Aggarwal, (2013) has investigated the impact of corporate governance on corporate financial performance in Indian context, using a sample of 20 companies listed on S\&P CNX Nifty 50 Index. Various tests like - regression, correlation, t-test and F-test have been performed using secondary data over a period of two years from FY 2010-11 to FY 2011-12 to study this linkage. She found that governance ratings have positive and significant impact on corporate financial performance.

In another context, Gupta \& Sharma (2014) studied various Corporate Governance practices followed by companies in India and South Korea. A sample of five multinational companies from each country is studied based on the Corporate Governance practices that are being followed by them. The study has checked whether higher and better corporate governance scores lead to better performance of the companies. It is found in the study that corporate governance practices have limited impact on both the share prices of the companies as well as on their financial performance. Likewise, Coşun \& Sayilir (2012) has explored the relationship between firm value and corporate governance (CG) of Turkish companies. The findings of the study do not support the hypothesis that better corporate governance is associated with higher firm values and better performance. Bansal \& Sharma (2016)examined the role of audit committee characteristics in addition with other components of corporate governance in improving firm performance. They found a significant positive association of board size and CEO-Chairman dual role with firm performance. However, findings did not reveal any additional effect of audit committee independence and its meeting frequency on the financial performance of Indian firms. Hassan et al., (2016) explored the relationship between corporate performance and corporate governance by companies listed on the Palestinian Stock Exchange. The result revealed that corporate performance is negatively associated with corporate governance. This implies that the result is inconsistent with agency theory. This might be due to the fact that corporate governance in Palestine is still at its infancy stage. Adjaoud et al., (2007) they found that there is no significant relationships between corporate governance and performance when using traditional performance measures, such as ROI, ROE, EPS and Market-to book value. The Significant links between board's quality and performance when the latter is captured by value performance measures, such as market value added and economic value added. Hassan \& Saadi (2013) investigated the effect of corporate governance mechanisms on the financial performance of the United Arab Emirates (UAE) listed firms. The results show that voluntary disclosure, CEO duality and board size are significantly influencing the UAE firms' performance measured (ROE and ROA), while none of the governance variables significantly affect firms' performance measured by Tobin's Q. Furthermore, the results reveal that firm size is the only control variable that significantly influences firms' performance. While other variables, such as board committees, audit type, industry, auditor type, leverage and listing years, are not significantly affecting firms' performance. Finally, Al-Manaseer et al., (2012) investigated empirically the impact of corporate governance dimensions on the performance of Jordanian Banks. The study reveals a positive relationship between corporate governance dimensions: the number of outside board members and foreign ownership and Jordanian banks' performance. Whereas, board size and the separation of the role of CEO and chairman have a negative relationship with performance.

Therefore, this study attempted to contribute to literature by introducing the following conceptual framework as shown in the Figure 1 to investigate the impact of corporate governance on the profitability.

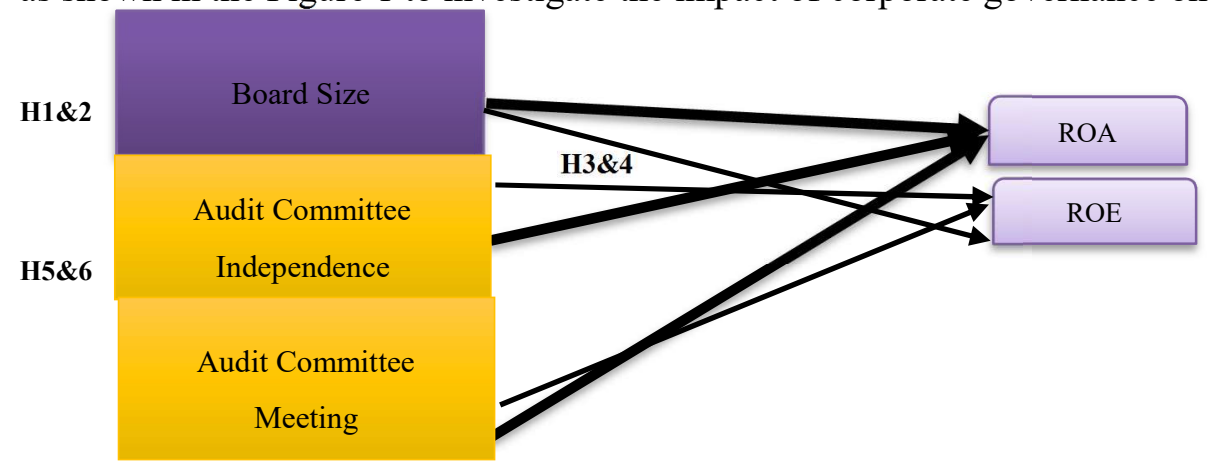

Figure 1: conceptual framework

Based on the literature review and objectives of the study demonstrated above, the hypotheses of the study are:

$\mathbf{H}_{\mathbf{0}} 1$ : There is no significant impact of board size on return on assets of Indian IT listed firms. 
$\mathbf{H}_{\mathbf{0}}$ 2: There is no significant impact of board size on return on equity of Indian IT listed firms.

$\mathbf{H}_{\mathbf{0}}$ 3: There is no significant impact of audit committee independence on return on assets of Indian IT listed firms.

$\mathbf{H}_{0} 4$ : There is no significant impact of audit committee independence on return on equity of Indian IT listed firms.

$\mathbf{H}_{\mathbf{0}}$ 5: There is no significant impact of audit committee meeting on return on assets of Indian IT listed firms.

Ho6: There is no significant impact of audit committee meeting on return on equity of Indian IT listed firms.

\section{Research Methodology}

2.1. Data collection and study period. This study is mainly conducted to investigate the impact of corporate governance on profitability in IT companies. For showing the impact, 20 top companies have been selected by their market capitalization. This study is based on the secondary data covering the period of 8 year i.e. from 2010 to 2017 which have extracted from the annual report individually from the website of the companies. Data relating to profitability and firm size have been taken out from Prowess IQ a database of Indian companies and Money control website ${ }^{4}$. The researchers used a panel data for eight years because panel data provide more informative data, more variability, less collinearity among the variables, more degrees of freedom and more efficiency.

\subsection{Concepts and measurements of variables in the study}

Table 1. Variables Definition

\begin{tabular}{|l|l|l|}
\hline \multicolumn{1}{|c|}{ Variable } & \multicolumn{1}{|c|}{ Measurement } & \multicolumn{1}{c|}{ References } \\
\hline \multicolumn{1}{|c|}{ Dependent variables } \\
\hline Return of Assets (ROA) & $\begin{array}{l}\text { It calculate by net income over total assets at the } \\
\text { end of the year. }\end{array}$ & $\begin{array}{l}\text { (Azim, 2012; Y. M. Hassan et al., 2016; } \\
\text { Rouf, 2012, Tabash, 2018) }\end{array}$ \\
\hline Return on Equity(ROE) & $\begin{array}{l}\text { It analyse by net profit / total equity at the end of } \\
\text { the year. }\end{array}$ & $\begin{array}{l}\text { (Aggarwal, 2013; Lin, 2011; Yahya et } \\
\text { al.,2017) }\end{array}$ \\
\hline \multicolumn{3}{|c|}{ Independent variables } \\
\hline Board Size & Total number of directors sits in the board & $\begin{array}{l}\text { (Al-Matari et al.,2012; Mohamed et al., } \\
\text { 2016) }\end{array}$ \\
\hline Audit Committee Meeting & Number of meetings held in a fiscal year & $\begin{array}{l}\text { (Y. A. Al-Matari et al., 2012; Bansal \& } \\
\text { Sharma, 2016) }\end{array}$ \\
\hline Audit Committee Independence & $\begin{array}{l}\text { Number of independent directors in the } \\
\text { committee }\end{array}$ & $\begin{array}{l}\text { (Y. A. Al-Matari et al., 2012; Bansal \& } \\
\text { Sharma, 2016) }\end{array}$ \\
\hline \multicolumn{1}{|c|}{ Control variable } \\
\hline Firm size & Natural logarithm of total assets. & (Aishah et al., 2016; Hassan et al.,2017) \\
\hline
\end{tabular}

2.3. Model Specification. Consistent with previous literature (Duppati et al., 2017; Villanueva et al., 2016) we developed the following model to investigate the effect of corporate governance mechanisms on portability.

$$
\begin{gathered}
R O A_{i t}=\alpha+\beta_{1} B S_{i t}+\beta_{2} A C M_{i t}+\beta_{3} A C I_{i t}+\beta_{4} F S I Z E_{i t}+\varepsilon_{i t} \\
R O E_{i t}=\alpha+\beta_{1} B S_{i t}+\beta_{2} A C M_{i t}+\beta_{3} A C I_{i t}+\beta_{4} F S I Z E_{i t}+\varepsilon_{i t}
\end{gathered}
$$

Where: $\alpha=$ intercept, $\varepsilon_{i t}=$ error term, $\beta=$ beta, $R O A_{i t}=$ Return on asset, $R O E_{i t}=$ Return on equity

$B S$ is the board Size of IT companies.

$A C M$ is the audit committee meetings.

$A C I$ is the audit Committee Independence.

FSIZE is the firm size.

\section{Results And Discussion}

3.1. Descriptive Statistics. Descriptive statistics of the variables used to estimate the regression models are summarized in Table 1. It is obvious from the table that the mean of corporate performance measured by ROA

\footnotetext{
${ }^{4}$ Money control is India's leading financial information source. See https://www.moneyworks4me.com
} 
for the sample as a whole during 2010-2017 was 4.26; ranging from -12 to 17. Similarly, the mean of corporate performance measured by ROE was 5.70. These are the dependent variables.

Table 2. Descriptive statistics

\begin{tabular}{|l|c|c|c|c|c|}
\hline & Observation & Minimum & Maximum & Mean & Std. Deviation \\
\hline ROA & 160 & -12 & 17 & 4.26 & 5.622 \\
\hline ROE & 160 & -16 & 27 & 5.70 & 9.872 \\
\hline BS & 160 & 4 & 9 & 6.36 & 1.295 \\
\hline ACM & 160 & 3 & 7 & 4.61 & 1.070 \\
\hline ACI & 160 & 3 & 6 & 3.70 & .725 \\
\hline FSIZE & 160 & 0.087 & 9 & 4.82 & 1.453 \\
\hline
\end{tabular}

The independent variables consist of corporate governance variables, i.e. board size, and audit committee meeting and audit committee independence. On the other hand here firm size is the control variables. Board size mean value is 9 for the period between 2010 and 2017. The minimum board size is 4 members and maximum board size is 9 members. Board size is important as directors sitting in the board to take decisions regarding the effective running of the firm. In audit committee meeting the mean value is 7 and here the minimum number of meeting held during 2010 to 2017 were 3 and the maximum number of meetings were 7. In the case of audit committee independence the minimum number of members were 3 and the maximum numbers were 7. This actually shows the strength of the firms and its performance. As a control variables firm-size its mean value is 4.82 and its range from 0.087 to 9 .

3.2. Correlation analysis. Table 3 presents the correlation matrix for the dependent and independent variables. Although the table reveals a number of significant correlations among the explanatory variables, the correlation coefficients are moderate and hence multicollinearity does not seem to pose any problem as shown in the table that the VIF for all variable lees than 2. It is worth mentioning that based on the observed high correlation between ROA and ROE, The correlation coefficient for many pair of variables is weak. However, there are three pairs that show a moderate correlation.

The first pair is Firm-size and audit committee independence with a negative correlation coefficient of -.045. The second pair is Board-size and audit committee independence with a positive correlation coefficient of $.208^{* *}$. The third pair is audit committee meeting and audit committee independence with a positive correlation coefficient of .409**. In the fourth, pair is ROA and audit committee independence with a negative correlation coefficient of -.044. Fifth pair is ROE and audit committee independence with a positive correlation coefficient of .058 . Since the correlations are relatively moderate, it indicates there is no multicollinearity problem and thus all the variables in the equal can be taken into the subsequent regression analysis.

Table 3. Pearson correlation matrix between corporate governance and profitability

\begin{tabular}{|c|c|c|c|c|c|c|c|}
\hline & & ROA & ROE & $\mathrm{BS}$ & $\mathrm{ACM}$ & AMI & GSIZE \\
\hline \multirow[t]{2}{*}{ ROA } & Correlation & 1 & & & & & \\
\hline & Sig. & & & & & & \\
\hline \multirow[t]{2}{*}{ ROE } & Correlation & $.392 * *$ & 1 & & & & \\
\hline & Sig. & .000 & & & & & \\
\hline \multirow[t]{2}{*}{$\mathrm{BS}$} & Correlation & $-.267 * *$ & -.003 & 1 & & & \\
\hline & Sig. & .000 & .486 & & & & \\
\hline \multirow{2}{*}{$\mathrm{ACM}$} & Correlation & -.094 & .055 & .109 & 1 & & \\
\hline & Sig. & .119 & .246 & .084 & & & \\
\hline \multirow[t]{2}{*}{$\mathrm{ACI}$} & Correlation & -.044 & .058 & $208^{* *}$ & $.409^{* *}$ & 1 & \\
\hline & Sig. & .292 & .233 & .004 & .000 & & \\
\hline \multirow[t]{2}{*}{ FSIZE } & Correlation & -.066 & .062 & $.136^{*}$ & .101 & -.045 & 1 \\
\hline & Sig. & 203 & .217 & .043 & .102 & 288 & \\
\hline \multicolumn{4}{|c|}{ Variance Inflation Factor } & 1.25 & 1.22 & 1.06 & 1.04 \\
\hline
\end{tabular}

3.3. The unit root test. Stationary of the study variables (dependents and independents) was tested using the Augmented Dickey-Fuller (ADF) test. Results of the ADF test, at the level, indicate that all variables are not stationary which lead to the fact that the unit root null hypothesis can't be rejected. The variables were then tested at the first difference. The results show stability of the data for all variables at the first difference. 
Table 4. Results of Augmented Dickey-Fuller test for Unit root

\begin{tabular}{|l|l|l|l|l|}
\hline \multirow{2}{*}{ Variable } & Level & First Difference & P-Value \\
\cline { 2 - 5 } & ADF statistics & P-Value & ADF statistics & 0 \\
\hline ACI & 51.0769 & 0.0763 & 65.7222 & 0 \\
\hline ACM & 42.8766 & 0.27 & 81.4319 & 0.0003 \\
\hline BS & 34.8367 & 0.5238 & 70.2134 & 0.0004 \\
\hline FSIZE & 37.6127 & 0.5782 & 77.2425 & 0 \\
\hline ROA & 48.2574 & 0.1737 & 92.4125 & 0 \\
\hline ROE & 38.9576 & 0.5171 & 91.6853 & \\
\hline
\end{tabular}

3.5. Regression analysis. Generalized method of moment (GMM) is used to test the study hypotheses through first difference with one lagged dependent variables, allowing for the modeling of a partial adjustment mechanism. Table 4 shows the results of testing the relationship between corporate governance mechanisms and profitability by generalized method of moment (GMM). The test is conducted at first difference by entering the dependent variables profitability measure by ROA \& ROE as the instrumental variable. According to Prob (J-statistic) of $(0.311432,0.674897)$ and AR (2) of $(0.282 \mathrm{O}, 0.8396)$, the models are fit and suitable to be tested.

Table 5. GMM estimation

\begin{tabular}{|l|l|l|l|l|l|l|l|l|l|}
\hline \multicolumn{2}{|l|}{ Model(1) ROA } & \multicolumn{1}{l|}{ Model(1) ROE } \\
\hline Variable & Coefficient & Std. Error & t-Statistic & Prob. & Variable & Coefficient & Std. Error & t-Statistic & Prob. \\
\hline ROA(-1) & 0.749006 & 0.039876 & 18.78357 & 0.0000 & ROE(-1) & -0.145311 & 0.049651 & -2.92664 & 0.0041 \\
\hline ACI & -3.34878 & 0.461361 & -7.25848 & 0.0000 & ACI & -8.056231 & 1.724411 & -4.67187 & 0.0000 \\
\hline ACM & 2.682556 & 0.433095 & 6.193922 & 0.0000 & ACM & -2.141934 & 1.398278 & -1.53183 & 0.1283 \\
\hline BS & 0.88035 & 0.271073 & 3.247652 & 0.0015 & BS & 0.794416 & 0.534014 & 1.487632 & 0.1396 \\
\hline FSIZE & -2.99417 & 0.506622 & -5.91006 & 0.0000 & FSIZE & -6.216056 & 1.920263 & -3.23708 & 0.0016 \\
\hline $\begin{array}{l}\text { Prob(J- } \\
\text { statistic) }\end{array}$ & 0.311432 & & & & $\begin{array}{l}\text { Prob(J- } \\
\text { statistic) }\end{array}$ & 0.674897 & & & \\
\hline AR(1) & 0.0085 & & & & AR(1) & 0.0467 & & & \\
\hline AR(2) & 0.2820 & & & & AR(2) & 0.8396 & & & \\
\hline
\end{tabular}

Results based on ROA Model. From table 4, it can be seen that the coefficient of the Audit committee Independence (ACI) is -3.34878 with P-value of 0.0000 . This means that the relationship between the two variables is negative and significant. This finding is in accordance with Al-Matari et al., (2014)in Portuguese context. It also noticed in table 5, the coefficient of the Audit committee meeting is 2.682556 with P-value 0.0000 . This means that the relationship between the two variables is positive and significant. This finding is consistent with the result of(Mandal \& Al-ahdal, 2018). Additionally, coefficient of the board size (BS) is 0.88035 with P-value 0.0015 . Thus, this relationship is positive and significant. This result is similar to the results of (Bansal \& Sharma, 2016). The control variable FSIZE has significant impact on profitability measure by ROA as $\mathrm{P}(\mathrm{v})=(0.0000)$

Results based on ROE Model. Similarly, based on the results presented in Table 5, the relationship between the audit committee independence (ACI) and ROE is negative and significant. This is in accordance with (Dhaliwal et al., 2006). From table 5, the coefficient of the audit committee meeting (ACM) is (2.141934) with P-value 0.1283. This means that the relationship between the two variables is negative and insignificant. This result is associated with (Al-Matariet al., 2014). Furthermore, table 5 shows that the coefficient of the board Size (BS) is 0.794416 with P-value 0.1396 . Accordingly, the relationship between the two variables is positive and insignificant, this result contradicts Conheady et al., (2015) who concluded that board size affect ROE positively. The control variable FSIZE has significant impact on profitability measure by ROE as P (v) $>(0.05)$.

\section{Conclusion}

The analysis of corporate governance and its impact on profitability is helpful to understand the actual performance of the firm. In this study we examine the impact of corporate governance on profitability in Indian IT companies listed on Indian stock exchanges and collected based on market capitalization for the period of 2010 to 2017. The dependent and independent variables of the research model i.e., return on assets, return on equity, compared with the Board Size, Audit Committee Meetings, Audit Committee Independence and control variable (firm size). 
By performing panel data GMM, the researchers found that board size and audit committee meeting have positive impact on return on assets. On the other hand, audit committee independence and firm's size are affecting return on assets negatively. Moreover, finding revealed that the audit committee meeting and audit committee independence impact the return on equity negatively except for board size. The findings contribute to the academicians to further extend the research in this area, the investors to make the investment decisions, and the regulators and policy makers to draft further rules and regulations with regards to profitability.

\section{Acknowledgements}

The authors gratefully acknowledge the helpful comments and suggestions received from the referees and the research assistance by Dr: Mosab Tabash. Besides, we would like to thank the financial support by Indian Council of Social Science Research.

\section{References}

1. Adjaoud, F., Zeghal, D., \& Andaleeb, S. (2007). The effect of board's quality on performance: A study of Canadian firms. Corporate Governance: An International Review, 15(4), 623-635. https://doi.org/10.1111 /j.1467-8683.2007.00592.x

2. Aggarwal, P. (2013). Impact of corporate governance on corporate financial performance. IOSR Journal of Business and Management, 13(3), 01-05. https://doi.org/10.9790/487X-1330105

3. Aishah, H., Muneer, H., Aishah, H., Muneer, H., Nahar, S., Jubb, C., \& Azim, M. I. (2016). Risk governance and performance: a developing country perspective. Managerial Auditing Journa, 31(3), 250268.http://doi.org/10.1108/MAJ-02-2015-1158

4. Alahdal, W. M., Alsamhi, M. H., \& Prusty, T. (2016). The role of cost accounting system in the pricing decision- making in industrial companies of Taiz city, Yemen. International Academic Journal of Accounting and Financial Management, 3(7), 70-78.

5. Al-ahdal, W. M., Farhan, N. H., M. I. T., \& Prusty, T. (2018). The impact of demonetization on Indian firms' performance: does company's age make a difference?. Investment Management and Financial Innovations , 15 (3), 71-82. doi:10.21511/imfi.15(3).2018.06

6. Al-Matari, E. M., Al-Swidi, A. K., \& Bt Fadzil, F. H. (2014). The effect of board of directors characteristics, audit committee characteristics and executive committee characteristics on firm performance in Oman: An empirical study. Asian Social Science, 10(11), 149-171. https://doi.org/10.5539/ass.v10n11p149

7. Al-Matari, E. M., Al-Swidi, A. K., \& Fadzil, F. H. B. (2014). Audit committee characteristics and executive committee characteristics and firm performance in Oman: Empirical study. Asian Social Science, 10(12), 98-113. https://doi.org/10.5539/ass.v10n12p98

8. Al-Matari, Y. A., Al-Swidi, A. K., \& Bt Fadzil, F. H. (2012). Corporate governance and performance of Saudi Arabia listed companies. British Journal of Arts and Social Sciences, 9(1), 1-30.

9. Al-Manaseer, M. F. A., Al-Hindawi, R. M., Al-Dahiyat, M. A., \& Sartawi, I. I. (2012). The impact of corporate governance on the performance of Jordanian banks. European Journal of Scientific Research, 67(3), 349-359.

10. Ararat, M., Black, B. S., \& Yurtoglu, B. B. (2017). The effect of corporate governance on firm value and profitability: Time-series evidence from Turkey. Emerging Markets Review, 30(November 2014), 113132. https://doi.org/10.1016/j.ememar.2016.10.001

11. Arora, A., \& Sharma, C. (2016). Corporate Governance and Firm Performance in Developing Countries: Evidence from India. Corporate Governance: The International Journal of Business in Society, 16(2). https://doi.org/doi.org/10.1108/CG-01-2016-0018

12. Azim, M. I. (2012). Corporate governance mechanisms and their impact on company performance: A structural equation model analysis. Australian Journal of Management, 37(3), 481-505. https://doi.org/10.1177/0312896212451032

13. Bansal, N., \& Sharma, A. K. (2016). Audit Committee, Corporate Governance and Firm Performance: Empirical Evidence from India. International Journal of Economics and Finance, 8(3), 103. https://doi.org/10.5539/ijef.v8n3p103

14. Bhardwaj, M. N., Batani, C., \& Rao, R. (2014). Corporate governance practices in india - a case study. Asia Pacific Journal of Research I Issue XIII, I(XIII), 2320-5504.

15. Conheady, B., Mcllkenny, P., Opong, K. K., \& Pignatel, I. (2015). Board effectiveness and firm performance of Canadian listed firms. British Accounting Review, 47(3), 290-303. https://doi.org/10.1016/j.bar.2014.02.002 
16. Coşkun, M., \& Sayilir, Ö. (2012). Relationship Between Corporate Governanceand Financial Performance of Turkish Companies. International Journal of Business and Social Science, 3(14), 59-64.

17. Dhaliwal, D., Naiker, V., Zealand, N., Navissi, F., East, C., \& Author, C. (2007). Audit Committee Financial Expertise, Corporate Governance and Accruals Quality : An Empirical Analysis. Ssrn.

18. Dhaliwal, D. S., Naiker, V., \& Navissi, F. (2006). Audit Committee Financial Expertise, Corporate Governance and Accruals Quality: An Empirical Analysis. Ssrn. https://doi.org/10.2139/ssrn.906690

19. Duppati, G., Sune, A., \& Samanta, N. (2017). Corporate governance, research and development volatility and firm performance - Evidence from Spain and Ireland. Cogent Economics \& Finance, 5(1), 1-16. https://doi.org/10.1080/23322039.2017.1317117

20. Gupta, P., \& Sharma, A. M. (2014). A Study of the Impact of Corporate Governance Practices on Firm Performance in Indian and South Korean Companies. Procedia - Social and Behavioral Sciences, 133, 4 11. https://doi.org/10.1016/j.sbspro.2014.04.163

21. Hassan, A. F. S., Karbhari, Y., Isa, A. A. M., \& Razak, N. H. A. (2017). Board Attributes and Performance of Government-Linked Companies (Glcs): Evidence From an Emerging Economy. Corporate Ownership and Control, 14(3). https://doi.org/10.22495/cocv14i3art8

22. Hassan, Y. M., Naser, K., \& Hijazi, R. H. (2016). The influence of corporate governance on corporate performance: Evidence from Palestine. Afro-Asian Journal of Finance and Accounting, 6(3), 269-287. https://doi.org/10.1504/AAJFA.2016.79296

23. Kamal Hassan, M., \& Saadi Halbouni, S. (2013). Corporate governance, economic turbulence and financial performance of UAE listed firms. Studies in Economics and Finance, 30(2), 118-138. https://doi.org/10.1108/10867371311325435

24. Lin, C. (2011). An examination of board and firm Performance: evidence from Taiwan. The International Journal of Business and Finance Research, 5(4), 17-35.

25. Mandal, P., \& Al-ahdal, W. M. (2018). Impact of Corporate Governance on Financial Performance. International Journal of Research, 5(19), 56-74. https://doi.org/10.5296/ber.v6i2.9772

26. Mohamed, S., Ahmad, K., \& Khai, K. (2016). Corporate Governance Practices and Firm Performance : Evidence from Top 100 Public Listed Companies in Malaysia. Procedia Economics and Finance, 35, 287 296. https://doi.org/10.1016/S2212-5671(16)00036-8

27. OECD. (2004). OECD principles of corporate governance, OECD Publishing. Available at: http://www.oecd.org/corporate/ca/corporategovernanceprinciples/31557724.pdf

28. Rouf, A. (2012). The Financial Performance and Corporate Governance Disclosure: A Study in the Annual Reports of Listed Companies of Bangladesh. Pak. J. Commer. Soc. Sci, 6(1), 1-11.

29. Tabash, M. I. (2018). An empirical investigation between liquidity and key financial ratios of Islamic banks of United Arab Emirates (UAE). Business and Economic Horizons, 14(3), 713-724

30. Tabash, M. I., Yahya, A. T., \& Akhtar, A. (2017). Financial Performance Comparison of Islamic and conventional banks in the United Arab Emirates (UAE). In International Conference on Advances in Business, Management and Law (ICABML), Dubai, 25-26 Nov. 2017, University of Dubai, 477-494.

31. Villanueva-Villar, M., Rivo-López, E., \& Lago-Peñas, S. (2016). On the relationship between corporate governance and value creation in an economic crisis: Empirical evidence for the Spanish case. BRQ Business Research Quarterly, 19(4), 233-245. https://doi.org/10.1016/j.brq.2016.06.002

32. Vishwakarma, R., \& Kumar, A. (2015). Does Corporate Governance Increases Firm Performance of It Industry? an Empirical analysis. Journal of Management Research, 7(2), 82-90.

33. Yahya, A. T., Akhtar, A., \& Tabash, M. I. (2017).The impact of political instability, macroeconomic and bank-specific factors on the profitability of Islamic banks: empirical evidence. Investment Management and Financial Innovations, 14(4), 30-39. http://doi.org/10.21511/imfi.14(4).2017. 